\title{
Impacts of mega-events on destination competitiveness and corruption perception in South American countries
}

\author{
Impactos dos megaeventos sobre a competitividade de destinos e corrupção percebida nos países sul americanos
}

Thays Cristina Domareski-Ruiz

Universidade Federal do Paraná, Brazil, thaysruiz@ufpr.br

\section{Adriana Fumi Chim-Miki}

Universidade Federal de Campina Grande, Brazil, adriana.chimmiki@gmail.com

Edar Añaña

Universidade Federal de Pelotas, Brazil, edarana@gmail.com

Francisco Antonio dos Anjos

Universidade do Vale do Itajaí, Brazil, fsanjos@terra.com.br

\begin{abstract}
Tourism destination competitiveness is a multidimensional concept that is widely studied in the academic literature. The corruption affects countries' business environment, generating negative image and barriers, so hindering its' ability to compete as a global player. This paper analyses this relation in the tourism industry in a sample of South American countries through a comparison within a five-year period based on the Travel and Tourism Competitiveness Index (TTCI) with the variation of Corruption Perception Index (CPI). An exploratory analysis to verify the upward and downward in these monitors was performed. The relation between $\mathrm{TTCl}$ and $\mathrm{CPI}$ was verified by a regression analysis. This research contributes directly to addressing a topic rarely explored in the tourism area, the influence of corruption perception in destination competitiveness. The results confirm that corruption perception impacts on tourism competitiveness of countries, but in presence of strong sources of tourism attractiveness, such as Mega events, this relation was reduced.
\end{abstract}

Keywords: Destination Competitiveness; Corruption; Mega-events; South-America; Destination Image.

\section{Resumo}

A competitividade dos destinos turísticos é um conceito multidimensional que é amplamente estudado na literatura acadêmica. A corrupção afeta ambiente de negócios dos países, gerando imagem negativa e barreiras, dificultando sua capacidade de competir como ator global. Este artigo analisa essa relação na indústria do turismo em uma amostra dos países sul americanos através de uma comparação dentro de cinco anos com base no Índice de Competitividade em Viagens e Turismo (TTCI) com a variação do Índice de Percepção de Corrupção (IPC) e faz uma análise exploratória para verificar a ascensão e descida nesses monitores. A relação entre TTCI e IPC foi verificada por análise de regressão. Esta pesquisa contribui diretamente para abordar um tópico raramente explorado na área do turismo, a influência da percepção de corrupção na competitividade do destino. Os resultados confirmam que a percepção de corrupção afeta a competitividade do turismo dos países, mas em presença de fortes fontes de atratividade turística, como megaeventos, essa relação foi reduzida.

Palavras-chave: Competitividade Turística; Corrupção; Megaeventos; América do Sul; Imagem do Destino.

\section{Introduction}

The contribution and benefits of the travel and tourism industry to the world economy is very significant, as tourism competitiveness is a growing topic in tourism studies. In a broad view, competitiveness is a construct that includes the concepts of sustainability, productivity and quality of life to local citizens (Porter, 1990; Ritchie and Crouch, 2003; Michael, Reisinger, \& Hayes, 2019).

Many factors influence the competitiveness and therefore it is important to use different approaches to study this topic. The abundance of natural, cultural and human resources, alongside a favorable business environment work as key factors for a destination to enhance competitiveness. Political stability, solid finance systems, good governance, economic wealth and governmental transparency, among other factors enable business environment (Dwyer and Kim, 2003). On the other hand, corruption is one of the most frequent topic in breaking news. Corruption is the practice of illegal activities, unethical and dishonest business carried out by a bureaucracy or by political leadership (Tanzi, 1998). The corruption also includes bribery among public officials and private agents in general, between two private companies or persons.

The effects of the crisis on tourism is a topic largely studied, however, the effects of corruption and the consequent crisis derived from this factor has been poorly explored in the tourism literature (Poprawe, 2015; Sara and Yap, 2015). The studies related to corruption impact on tourism are restricted to case studies involving specific countries, for instance, the researches of Duffy (2000) or Henderson (2003). Meanwhile, some studies found a correlation between the perception of corruption and tourism competitiveness (see, Das and DiRienzo, 2010), and others, even more recent, suggest that corruption perception does correlate to tourism arrival (see, Lau and Hazari, 2011). Poprawe (2015) also studied the connection between corruption and tourist flows in 100 countries and showed that $1 \%$ reduction in the perceived corruption improves $2-7 \%$ of tourist flow, especially in the countries of temperate climate. 
Nevertheless, the study of Yap and Saha (2013) pointed out that in countries with historic and natural heritage, the tourism demand may not be affected by the worsening in the corruption perception. Although these results seem to lead to an inconclusive situation, it is a clear indication that the level of corruption affects the tourism competitiveness, but in the presence of a factor able to modify the regular demand, this misfortune may not occur.

Mega-events are large-scale cultural or sporting events which have a mass population appeal, international significance (Roche, 2000); It is an important component of the tourism system and has important implications for the host area (Getz and Page, 2016), becoming sometimes an important instrument for urban regeneration and a strategic marketing instrument for host nations (Mirzayeva, Turkay, Akbulaev, \& Ahmadov, 2020). The literature also presents that the implications of mega-events for the hosting city can either be positive or negative, impacting in the economy, in tourism destinations, in the infrastructure, in legacy and to the local population (Preuss and Schuette, 2016; Tasci et al., 2019; Ferreira; Giraldi, 2019). The relationship between the concepts of hosting mega-events and corruption perception has grown over the years (Das and Dirienzo, 2010; Saha and Yap, 2015; Hundt and Horsch, 2018; Olmos; Bellido; Román-Aso, 2020).

Thus, considering the low number of studies on corruption to the tourism sector, this research intends to confirm two assumptions: (1) there is a correlation between the level of corruption and tourism competitiveness at the destination level; (2) an impactful event on tourism demand eliminates the correlation between corruption and tourism competitiveness. To answer these questions, South American countries were analyzed.

The value of this paper is due to the majority of researches on destination image and tourism competitiveness being associated with the attraction of tourists, but not considering the power of corruption perception. The importance of tourism destination image is universally acknowledged for affecting people's subjective perception, behavior and the destination choice (Walmsley and Young, 1998), influencing directly in the destination competitiveness. Furthermore, corruption harms the destination brand and puts away the foreign investment, affecting the internationalization process. More studies about this theme are evidently necessary.

This paper is structured in four sections. The next section reviews the literature on the connection between corruption and tourism competitiveness. Data descriptions section presents the data models and methodology. The results section presents and discusses the empirical data and the analyses performed. The final section provides the conclusion and policy implications.

\section{Theoretical background between corruption and tourism competitiveness}

The global institutions of economic monitoring consider that competitiveness is generated by the set of institutions, policies, and factors that determine the productivity of a country (TTCl, 2015). Tourism competitiveness is the ability of a destination to attract potential tourists and offer a tourism experience more satisfying than its competitors, and thus improving the national wealth in an economic model that generates opportunities for the local people (Ritchie and Crouch, 2003; Dwyer and Kim, 2003; Bahar and Kozak 2007; Hong, 2009). The tourism literature on competitiveness has grown in the past 30 years. Researchers have focused their attention on groups of variables that affect competitiveness, featuring a large variety of approaches (Ritchie and Crouch, 2003; Dwyer and Kim, 2003; Salinas Fernández, et al., 2020).

A strategy used by countries to optimize tourism competitiveness is to host mega-events to publicize the country's image as a tourism destination (Wan and Song, 2019). The mega-events tend to have long-term and synergistic effects on destinations (Getz and Page, 2016). They are large-scale and have publicity, financial budgets and international participation. For instance, the largest global sporting events such as the Summer Olympic Games, the Winter Olympic Games and FIFA Football World Cup (Ren and Li, 2019).

The connection between tourism competitiveness and crisis, including climatic, epidemic, political, economic occurrences and other social crisis is also widely studied. The uncertainty related to security during vacations and leisure time generated by political violence, crime, terrorism, foreign exchange and others, significantly hinder tourism development (Neumayer, 2004; Eilat and Einav, 2004; Gauci et al., 2002; George, 2003). In this context, the intense global competition in the tourism industry forces destinations to develop unique and competitive destination brands. Literature suggests that corruption affects countries' business environment, generating negative barriers, hindering its ability to compete as a global player and consequently reducing the countries' brand equity (Lamsdorff, 2003). However, there are few studies that relate insecurity perceived by tourists due to corruption (Poprawe, 2015), as well as, studies that analyze the effect of corruption on tourism competitiveness.

An illegal payment to a public official to obtain a personal benefit or for the firm can be considered corruption (RoseAckerman, 1999), but the correct concept is the illegitimate use of resources or public functions to generate private benefits (Bicchieri and Duffy, 1997). That is an act in which the power of public office is used for personal gain in violation of preestablished rules (Aidt, 2003).

Two previous studies of Leff (1964) and Huntington (1968) were pioneers in corruption and tourism researches. These authors stated that corruption could increase the tourism demand through two mechanisms. The first one occurs because the corruption practices streamline bureaucracy in obtaining visas allowing more visitors. The second is because the government officials work more to be able to charge more bribery. Nevertheless, Myrdal (1968) presented a different perspective: 
in his view, the employees slow the process in order to attract more bribery, so fewer visitors enter the country.

Economic studies generally show that corruption increases the cost of an economy and affects the country's growth (RoseAckerman, 1978). The tourism research related to corruption has focused on the impact of bribes that generate additional costs to the tourist and more time to obtain a visa. In this way, two streams of studies have been formed. The first stream considers that corruption acts as an extra tax (Aidt, 2003), increasing travel costs and thus reducing the attractiveness of the country as a tourism destination. This current is based on empirical theoretical assumptions of corruption as 'Sanding the wheels of growth' (Méon and Sekkat, 2005). While the second stream considers that corruption makes the country more efficient because it facilitates the bureaucracy of the public sector. It is based on the proposition of corruption as 'Greasing the wheels of growth' (Dreher and Gassebner, 2013), affecting especially the economies highly regulated.

Both currents have supporters, despite the increase in costs for tourism as a whole and for tourists' expenditures, in particular, the corruption can have some advantages for tourism firms and for tourists themselves. For example, it generates an increase in business activity and money spending and, for tourists, generates more facilities due to bribes (Poprawe, 2015).

Another approach to the effect of corruption on tourism competitiveness is based on the illegality's effects of the natural resources use in the country. Following this line of thought, Ikiara and Okech (2002) studied the Kenyan government's inability to control the stakeholder groups that caused a large environmental degradation, threatening the ecotourism development. Thus, political corruption and constant changes in leadership in this country have been identified as the main factor that negatively affects the environmental conservation efforts in Kenya.

The models of tourism competitiveness and monitors have a premise of cause and effect. Therefore, they consider that the competitive potential will be transformed into abilities and results consequently generating productivity (Croes and Kubickova, 2013). It assumes that better infrastructure, climate, natural resources, etc. will generate a good tourist flow. However, this relation may not occur because other variables act on the country's image, changing its attractiveness power.

The transparency in policymaking, safety and security and the lack of corruption are relevant determinants of tourism competitiveness, since the country's ability to establish a steady business and economic environment helps the tourism sector to prosper (Dwyer and Kim, 2003). According to previously exposed, the tourism competitiveness does not reflect the tourist demand, but a set of factors that attract and support the development of tourism. Therefore, the tourism competitiveness acts directly on the country's ability to attract investments and investors to the sector.
Poprawe (2015) indicated that wealthy, open and fast-growing countries attract more tourists than poor countries. Given this perspective, the effects of corruption on tourism are undeniable, since it negatively affects the business and sector's performance (Sara and Yap, 2015). Moreover, the competitiveness of this industry can also be affected because commonly, corruption in government agencies generates a monopolistic market that restricts the entry of small businesses and creates a high price to be paid by the final consumer (McKercher and Robbins, 1998). These studies indicate a negative correlation between corruption and tourism competitiveness. However, the Transparency International (2012) stated that $70 \%$ of the countries still have incidents of bribery and that the vast majority are emerging economies, which had bigger growth in its tourist flow than advanced economies.

Few studies analyzed the relationship between mega-events and corruption. However, some insights were provided by some scholars, although on the perspective of citizens. Nunkoo, Ribeiro, Sunnassee, \& Gursoy (2018) showed the connection among corruption, transparency, knowledge, and public trust using data collected from Brazilians in the context of the 2014 FIFAWorld Cup Games.

In the same way, Aksu et al. (2019) already focused on trust level by local people on the organizing committee of events considering the government, corruption and transparency. Results indicated that citizens believe there is corruption in the planning and management processes of events. Still, there is an improvement in the tourism destination reputation, as well as, the destination image to the world by ensuring the international media appearance (Aksu et al. 2019).

Recently, a research pointed out the selection of the host country, rather than the celebration of the mega-event itself, positively impacts the corruption perceived by citizens related to diverting funds for private gain, lack of transparency in the decision-making process, especially in the selection of service and construction contracts (Olmo, Bellido, \& Aso, 2020). Another viewpoint related to mega-events and corruption was offered by Hundt \& Horsch (2019). They studied the negative returns after the latest corruption scandals around FIFA became public. Nevertheless, the relationship between tourism, corruption, and mega-events under the tourist or destination competitiveness perspective is understudied.

\section{Data descriptions and methodology}

The research used secondary data because is an exploratory step, in order to provide a first overview of the connection of corruption and tourism competitiveness in the presence of mega-events, due to a scarcity of researches on this topic. International institutions provided the secondary data which methodology includes hard data (national statistical information) and soft data (based on entrepreneurial surveys and the public sector). The benefit of these data is that they cover a large set of countries for the period of 2008-2016. 


\subsection{Tourism Competitiveness}

The World Economic Forum (WEF) verifies the level of country's competitiveness through the Travel and Tourism Competitiveness Index (TTCI). Thus, in this research the raw data on tourism are based on TTCI, that includes detailed profiles for each of the 141 economies featured in the study, as well as an extensive section of data tables with global rankings covering 90 indicators grouped in four sub-index: Enabling Conditions; $T$ \& $T$ Policy and Enabling Conditions; Infrastructure; and, Natural and Cultural Resources. These indicators are divided into 14 pillars: (1) Business Environment, (2) Safety and Security, (3) Health and Hygiene, (4) Human Resources and Labour Market, (5) ICT Readiness, (6) Prioritization of Travel and Tourism, (7)International Openness, (8) Price Competitiveness, (9) Environmental Sustainability, (10) Air Transport Infrastructure, (11) Ground and Port Infrastructure, (12) Tourist Service Infrastructure (13) Natural Resources, (14) Cultural Resources and Business Travel. In the end, the main dependent variable is Tourism Competitiveness (TTCl), expressed on a scale of 7 points, being the higher rank, the higher tourism competitiveness.

\subsection{Corruption Perception}

The independent variable in this analysis is corruption, based on the Corruption Perceptions Index (CPI) calculated by the Transparency International Organization. The Corruption Perceptions Index aggregates data from a number of different sources that provide perceptions of business people and country experts about the corruption level in the public sector. The CPI-2015 was calculated from 12 different data sources, available from 11 different institutions, able to capture perceptions of corruption within the past two years (Transparence International, 2015). Data derived from: (1) African Development Bank Governance Ratings, (2) Bertelsmann Foundation Sustainable Governance Indicators, (3) Bertelsmann Foundation Transformation Index, (4) Economist Intelligence Unit Country Risk Ratings, (5) Freedom House Nations in Transit, (6) Global Insight Country Risk Ratings, (7) IMD World Competitiveness Yearbook, (8) Political and Economic Risk Consultancy Asian Intelligence, (9) Political Risk Services International Country Risk Guide, (10) World Bank Country Policy and Institutional Assessment, (11) World Economic Forum Executive Opinion Survey (EOS), and (12) World Justice Project Rule of Law Index.

CPI is an impartial index, that covers a significant number of countries, and is one of the most comprehensive and robust measures of corruption (Serra, 2006). The index range is from zero to 100 in a reverse way: the higher the score, the lower the corruption perception. Despite being an index of perception (and not a manifest variable) CPI is frequently used as a measure of corruption in studies related to the country's competitiveness and tourism attractiveness. Floyd and Pennington-Gray (2004) indicate that the country's negative image impacts on tourists' choice, even if no real fact justifies it.

\subsection{Controls}

Many variables interfere on tourism competitiveness and on the tourist flow. This research evaluates the tourism competitiveness regarding the corruption perception in presence of a mega-event able to modify the tourism demand. So, in attendance to the objective of this research, a Dummy Variable was created to represent the mega event occurred in one of the countries included in the analysis.

Mega-events are cultural events (including the commercial and sports events) able to produce dramatic changes in mass movements internationally (Roche, 2000). In general is a good advertise to a city or a country, because it shows the culture and traditions of the event organizers, reinforcing its message and building a desired image to the world, increasing the tourism flows (Roche, 2000; Getz and Page, 2016; Mirzayeva, Turkay, Akbulaev, \& Ahmadov, 2020).

\subsection{The context of analysis}

Figure 1 shows the variation on corruption and tourism competitiveness indexes for twelve South American countries monitored by TTCI and CPI. If taken together, the group of countries analyzed has reduced the corruption level $7.69 \%$ and improved their tourism competitiveness $5.59 \%$. In general, the American countries that improved the CPI index also improved the TTCl; Chile was an exception, the only country in the group that improved tourism competitiveness regardless the downgrade in the corruption control.

Venezuela faced a downgrade in both indexes: $-10.53 \% \mathrm{CPI}$, and $-9.48 \% \mathrm{TTCl}$, probably due to the political and economic degradation in the period. Brazil seems to be a special case: the CPI improved a little from 2011-12, remained stable within the next two years, and suffered a hard influx in 2015 , coming back to the same level as it was in 2011. However, despite the ups and downs in the corruption perception level, the tourism competitiveness index showed a tendency of high during all the period, with a sharp peak in 2013, throughout the preparation for the FIFA World Cup. That is, Brazil had maintained a reduced perception of corruption during the preparation to the World Cup since the higher CPI means lower corruption. 
Figure 1 - CPI and TTCl variation of South American Countries during 2011-2015

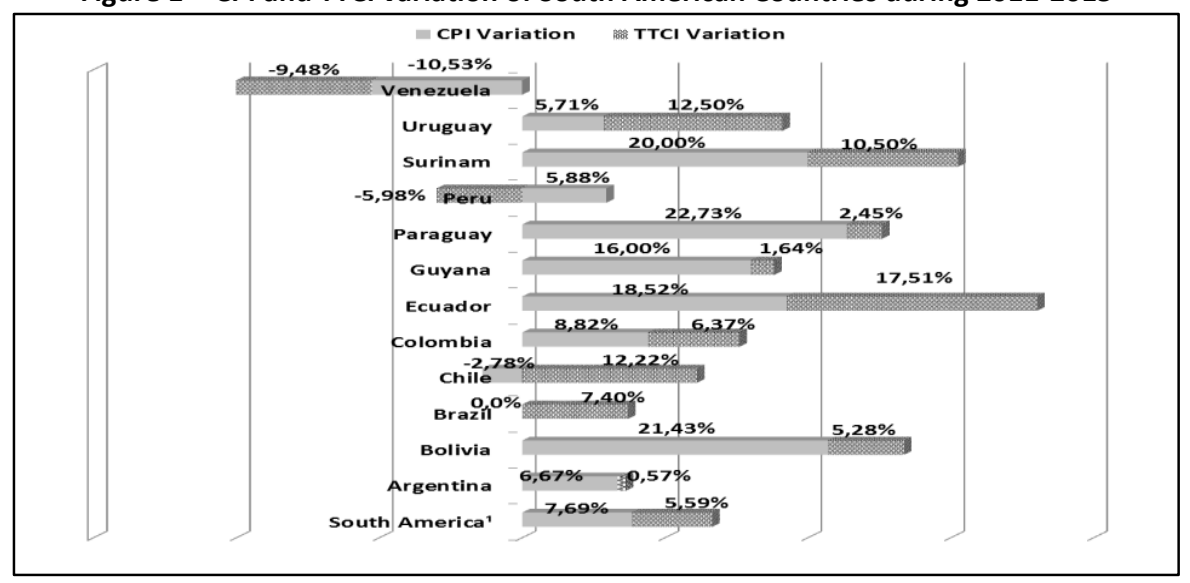

Source: Elaborated by authors based on TTCI and CPI Indexes, 2016.

\subsection{Methodology Procedures}

As a preliminary step, we performed an exploratory analysis to verify the movements (upward and downward) in TTCl and CPI for South American countries. Linear regressions with the twelve listed countries were performed to evaluate possible dependency of TTCI to CPI, but the adjusted level was poor.

To stress the discrepancies, it was estimated the slope for CPI in the last four years and selected the countries with most pronounced ups and downwards. Argentina, Venezuela, Peru, and Brazil showed the most worrying corruption recrudescence on that period; and Uruguay, Paraguay, Guyana and Colombia showed upward slopes. For convenience, countries with stable CPI (Bolivia, Ecuador and Suriname) and those with incomplete data (Suriname, Guyana and Paraguay) were not included in the next step. Countries selected for the estimation in the next step are in bold in the sloping column on Table 1.

Table 1 - Corruption Perception Tendency

\begin{tabular}{|l|c|c|c|c|c|c|}
\hline COUNTRY & $\mathbf{2 0 1 1}$ & $\mathbf{2 0 1 2}$ & $\mathbf{2 0 1 3}$ & $\mathbf{2 0 1 4}$ & $\mathbf{2 0 1 5}$ & Slope \\
\hline Argentina & 30 & 35 & 34 & 34 & 32 & $\mathbf{- 0 , 9}$ \\
\hline Bolivia & 28 & 34 & 34 & 35 & 34 & 0,1 \\
\hline Brazil & 38 & 43 & 42 & 43 & 38 & $\mathbf{- 1 , 4}$ \\
\hline Chile & 72 & 72 & 71 & 73 & 70 & $-0,4$ \\
\hline Colombia & 34 & 36 & 36 & 37 & 37 & $\mathbf{0 , 4}$ \\
\hline Equator & 27 & 32 & 35 & 33 & 32 & $-0,2$ \\
\hline Guyana & 25 & 28 & 27 & 30 & 29 & 0,6 \\
\hline Paraguay & 22 & 25 & 24 & 24 & 27 & $\mathbf{0 , 6}$ \\
\hline Peru & 34 & 38 & 38 & 38 & 36 & $-\mathbf{0 , 6}$ \\
\hline Suriname & 30 & 37 & 36 & 36 & 36 & $-0,3$ \\
\hline Uruguay & 70 & 72 & 73 & 73 & 74 & $\mathbf{0 , 6}$ \\
\hline Venezuela & 19 & 19 & 20 & 19 & 17 & $-\mathbf{0 , 7}$ \\
\hline
\end{tabular}

\section{Results}

It was observed the existence of a significant correlation between CPI-2015 and TTCl-2015 amongst 137 countries (Pearson Correlation=0.785). It is evident that corruption perception tends to influence tourism competitiveness at the country level, in normal situations. The first attempt to model $\mathrm{CPI}$ as a conditioning variable for $\mathrm{TTCl}$ showed a significant association, but value for R2(0.691) was considered insufficient by the authors. These results included seven countries during the period, i.e, $\mathrm{N}=\mathbf{2 8}$. The regression model in this phase was:
In order to reach a more reasonable adjustment, a Dummy variable was created and set to zero or to one $|0-1|$ for the country hosting a mega event (Brazil), in the years included in the event window. Three successive regression analysis were performed testing Brazil as a special case (Dummy=1) for the years 2013, 2013-14, and 2013-15 (Table 2). Results showed a progressive improvement in $\mathrm{R} 2$ values $(0.691$ for the model with no Dummies; 0.769 for the model with a Dummy in 2013; 0.788 for the model with Dummies in 2013-14 and 0.849 for the model with Dummies in 2013-15). 
Table 2 - Results of progressive Linear Regression Analysis

\begin{tabular}{|c|c|c|c|c|c|}
\hline & COEFFICIENTS & STANDARD ERROR & STAT $\mathrm{t}$ & VALUE-P & $\mathbf{R}^{2}$ \\
\hline \multicolumn{5}{|c|}{ Model with all Dummies $=0$} & \multirow{4}{*}{0.691} \\
\hline Constant & 2.69 & 0.14 & 19.64 & 0.000 & \\
\hline $\mathrm{CPI}$ & 0.25 & 0.03 & 7.47 & 0.000 & \\
\hline EVENT (Dummy variable) & 0.00 & 0.00 & & & \\
\hline \multicolumn{5}{|c|}{ Model with Dummy = 1 for Brazil 2013} & \multirow{4}{*}{0.769} \\
\hline Constant & 2.68 & 0.12 & 22.62 & 0.000 & \\
\hline $\mathrm{CPI}$ & 0.24 & 0.03 & 8.49 & 0.000 & \\
\hline EVENT (Dummy variable) & 0.72 & 0.25 & 2.91 & 0.008 & \\
\hline \multicolumn{5}{|c|}{ Model with Dummies = 1 for Brazil 2013-14 } & \multirow{4}{*}{0.788} \\
\hline Constant & 2.68 & 0.11 & 23.59 & 0.000 & \\
\hline $\mathrm{CPI}$ & 0.24 & 0.03 & 8.74 & 0.000 & \\
\hline EVENT (Dummy variable) & 0.58 & 0.17 & 3.39 & 0.002 & \\
\hline \multicolumn{5}{|c|}{ Model with Dummies = 1 for Brazil 2013-15 } & \multirow{4}{*}{0.849} \\
\hline Constant & 2.65 & 0.10 & 27.68 & 0.000 & \\
\hline $\mathrm{CPI}$ & 0.24 & 0.02 & 10.36 & 0.000 & \\
\hline EVENT (Dummy variable) & 0.62 & 0.12 & 5.13 & 0.000 & \\
\hline
\end{tabular}

Source: Elaborated by authors.

Thus, the final regression model to $\mathrm{TTCl}-\mathrm{CPI}$, with a p-value of 0.000 can be expressed by:

Results confirmed that CPI influences $\mathrm{TTCl}$ and that countries with lower levels of corruption tend to enjoy higher levels of tourism competitiveness and vice-versa. But this tendency was modified during the years surrounding a mega event when the country's effort concentrates in preparing the structure to host the event and, as a consequence, obtain great attention from the international media. In other words, when the country hosts a mega event, the tourism competitiveness level raises 0.62 .

These outcomes are enough to answer the two stated questions. The answer to the first question is yes, because the connection between $\mathrm{CPI}$ and $\mathrm{TTCl}$ is direct and positive. It is possible to say that tourism competitiveness tends to improve when a country succeeds in controlling the corruption and the opposite happens when corruption recurs. The answer to the second question is also positive. When a country prepares to host an impacting event like the Olympic Games or The FIFA World Cup, the tourism demand tends to improve regardless the corruption perception and this improves the Tourism Competitiveness Index, in spite of any improvement in the Corruption Perception Index.
$T T C l=2.65+0.24 C P I+0.62 E V E N T$

In the analyzed case, the organization of the FIFA World Cup 2014 improved the tourism competitiveness due to the large investments (public and private), policies of attraction, facilities for fast visas and other special conditions. This context minimized the effects of corruption on both, the tourism demand and the tourism competitiveness.

Figure 2 presents the connection between $\mathrm{CPI}$ and $\mathrm{TTCl}$ in the last four years. As we can see by the blue arrows, the two countries that most advanced in the corruption control (Uruguay and Colombia) also improved their TTCI. Argentina and Venezuela sunk in the opposite way: they degenerated in corruption perception and lost precious space in the tourism competitiveness. Paraguay experienced some comes and goes in both indexes without a clear tendency. Brazil seems to be a special case: although experiencing a clear degradation in corruption control in the last four years, the tourism competitiveness showed sharp advances in 2013 - the year preceding the FIFA World Cup - and part of these gains remained in the following two years.

Figure 2 - TTCI in relation to CPI in the period 2012-15

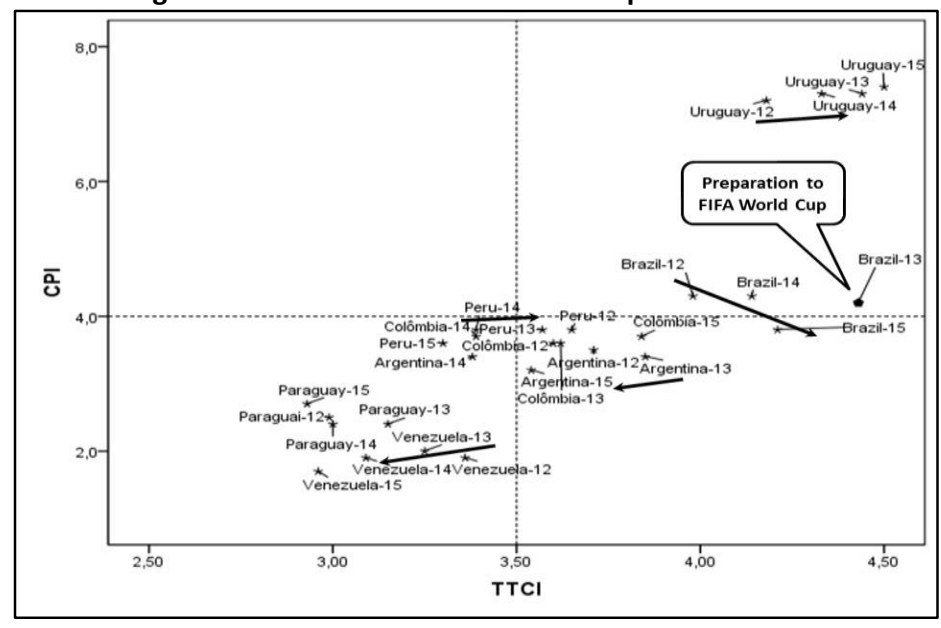

Source: Elaborated by authors 


\section{Conclusions and implications}

There are innumerous researches about the effects of megaevents. Several authors confirm that hosting mega-events provides to the city legacy, an improvement in destination image worldwide and destination reputation, influencing positively in infrastructure transformation in the city. On the other hand, corruption is a theme that was not largely investigated by academicians in tourism area (Olmos et al, 2020). Corruption affects trust and transparency perceptions of people and consequently the destination image.

From 2011 to 2015, the corruption perception in South America decreased $7.68 \%$, so the countries moved upward on CPI. Only two countries from the sample (Chile and Venezuela) showed more corruption. However, the variation was too small in some cases, so it practically remained stable in the perception corruption level of six countries. There are high variations into the sample since one of the economies improved $22.7 \%$ (Paraguay) while one of them decreased $-10.5 \%$ (Venezuela). Due to those facts, the existence of outliers is considered. The same situation occurs with $\mathrm{TTCl}$, only two economies lost tourism competitiveness (Peru and Venezuela). The countries analyzed gain $5.38 \%$ of competitiveness in the tourism industry. This scenario indicates an improvement in the region that tends to strengthen the South American economy.

For convenience, only the countries that presented more expressive upgrades or higher corruption were included in the final analysis. Results suggest that corruption influences the tourism competitiveness level, but this effect may be mitigated while the country is hosting a mega event. Countries that reduced the corruption also tended to improve $\mathrm{TTCl}$ and the opposite happened to that one in which corruption became more visible. Brazil was found an outlier: although the huge depth in the CPI, the country progressed expressively in 2013, during the preparation for the FIFA World Cup and part of those gains remained during the following years.

In another viewpoint of the study of Olmos et al (2020), that also analyzed mega-events and corruption, our research reveals different results. Results from Olmos et al (2020) indicated corruption inside the process of mega-events is perceived by the local community and generated a negative effect. Our results, on one side, confirm this negative effect, because they showed that corruption decreases the tourism competitiveness. However, on the other side, a mega-event reduces this effect on the tourist perception, so a mega-event mitigated the negative effect of corruption on the tourism competitiveness.

The regression analysis considering the existence of the megaevent in the country as a dummy variable during the study period showed a level of significance to the connection of corruption and tourism competitiveness. Moreover, this connection between the countries of South America explains $85 \%$ of the variance of $\mathrm{TTCl}$, thus the model has a good fit.
These results are twofold. First, if a country wants to improve its competitiveness, it should give better attention to policies that curb corruption, because it works as tourism investments and in an attraction of tourists. This viewpoint follows the assumption 'Greasing the wheels of growth' (Dreher and Gassebner, 2013), affecting especially the highly regulated economies. This theoretical stream indicates that some degree of corruption can be beneficial to accelerate the tourist flow, due to the facilitation allowed by some visa office's agents. However, that does not apply to all countries, because if there are no barriers or high bureaucracy to enter the country, this assumption is not confirmed. So the corruption, in the analyzed group, will be an ally to accelerate the tourism flow in very few countries. Instead, it could be considered that the existence of corruption can help in the acceleration of procedures to start a business in the country.

Especially because the variable that measures the time of this procedures is, in most cases, uncompetitive in Latin American. This argument lacks evidence but should not be ruled out, since competitiveness also depends on the volume of tourism business. On the other hand, corruption also acts as an extra tax (Aidt, 2003), increasing travel costs and consequently reducing the attractiveness of the country as a tourism destination, so this way can be 'Sanding the wheels of growth' (Méon and Sekkat, 2005).

A second interpretation of the research results is that, in the absence of effective tools and police to reduce corruption, the country can use the mega-events to minimize the effect of corruption, accelerating the attraction of investments and infrastructure, improving the destination image and generating high tourism flow. Therefore, it is another way to represent the 'Greasing the wheels of growth approach' by Dreher and Gassebner (2013).

At sum, this research contributes for addressing a topic seldom explored in the tourism literature: the influence of corruption perception in the tourism competitiveness. Up to this moment, most of the researches on destination image and the tourism competitiveness are associated with the power to attract tourists. However, the destination power to attract investors also influences on country's competitiveness (Das and Dirienzo, 2010). Corruption harms the destination brand and puts away the foreign investment, affecting the internationalization process.

More studies about this theme are clearly necessary, especially in South America and other regions with high levels of corruption. In addition, a research using the sample of countries in different stages of economic development is recommended for the further research. It would also be interesting the attempt of any other quantitative technique. Likewise, clusters of economies with similar cultural features or trade openness level can be used. At last, the major limitations of the study are the scarcity of data and reference on corruption studies applied to the tourism sector and, the small sample limits the overview on the topic. 


\section{References}

Aidt, T. S. (2003). Economic analysis of corruption: a survey. The Economic Journal, 113(491), 632-652.

DOI: https://doi.org/10.1046/j.0013-0133.2003.00171.x

Akın, A., Selin, A., Olcay, Y. E., \& Beril, E. (2019). Attitudes of local people in terms of government trust, knowledge, transparency and corruption in international festivals: International Antalya Film Festival example. Turizam, 23(4), 190-203. DOI: 10.5937/turizam23-24387.

Bahar, O., \& Kozak, M. (2007). Advancing destination competitiveness research: Comparison between tourists and service providers. Journal of Travel \& Tourism Marketing, 22(2), 61-71.

Bicchieri, C., \& Duffy, J. (1997). Corruption cycles. Political Studies, 45(3), 477-495. DOI: https://doi.org/10.1111/14679248.00092

Croes, R., \& Kubickova, M. (2013). From potential to ability to compete: Towards a performance-based tourism competitiveness index. Journal of Destination Marketing \& Management, 2(3), 146-154. DOI: https://doi.org/10.1016/j.jdmm.2013.07.002

Ritchie, J. B., \& Crouch, G. I. (2003). The competitive destination: A sustainable tourism perspective. Cabi.

Das, J., \& DiRienzo, C. (2010). Tourism competitiveness and corruption: A cross-country analysis. Tourism economics, 16(3), 477-492. DOI: https://doi.org/10.5367/000000010792278392

Dreher, A., \& Gassebner, M. (2013). Greasing the wheels? The impact of regulations and corruption on firm entry. Public Choice, 155(3-4), 413-432. DOI: https://doi.org/10.1007/s11127-011-9871-2

Duffy, R. (2000). Shadow players: ecotourism development, corruption and state politics in Belize. Third World Quarterly, 21(3), 549-565. DOI: http://dx.doi.org/10.1080/713701038

Dwyer, L., \& Kim, C. (2003). Destination competitiveness: determinants and indicators. Current issues in tourism, 6(5), 369-414. DOI: http://dx.doi.org/10.1080/13683500308667962

Eilat, Y., \& Einav, L. (2004). Determinants of international tourism: a three-dimensional panel data analysis. Applied Economics, 36(12), 1315-1327. http://dx.doi.org/10.1080/000368404000180897

Ferreira, L. B., \& Giraldi, J. D. M. E. (2020). Rio de Janeiro's image as the 2016 Olympic Games host city: analysis of the main image formation factors. Journal of Hospitality and Tourism Insights. In Press. DOI 10.1108/JHTI-03-2019-0037

Floyd, M., Pennington-Gray, L., \& Thapa, B. (2003). The Effects of Risk Perception on Intention to Travel in the Aftermath of September 11, 2001. Safety and Security in Tourism: relationships. Journal of Travel \& Tourism Marketing, 15, (2-3), 19-38, DOI: 10.1300/J073v15n02_02

I Gauci, A., Gerosa, V., \& Mwalwanda, C. (2002). Tourism in Africa and the multilateral trading system: challenges and opportunities. Addis Abeba: Background Paper for the Economic Commission for Africa.

George, R. (2003). Tourist's perceptions of safety and security while visiting Cape Town. Tourism Management, 24(5), 575-585. DOI: https://doi.org/10.1016/S0261-5177(03)00003-7

Getz, D., \& Page, S. J. (2016). Progress and prospects for event tourism research. Tourism Management, 52, 593-631.

Henderson, J. C. (2003). The politics of tourism in Myanmar. Current Issues in Tourism, 6(2), 97-118. DOI: http://dx.doi.org/10.1080/13683500308667947

Hong, W. C. (2009). Global competitiveness measurement for the tourism sector. Current Issues in Tourism, 12(2), 105-132. DOI: http://dx.doi.org/10.1080/13683500802596359

Hundt, S., \& Horsch, A. (2019). Sponsorship of the FIFA world cup, shareholder wealth, and the impact of corruption. Applied Economics, 51(23), https://doi.org/10.1080/00036846.2018.1545082 2468-2491.

Huntington, S. (1968). Political Order in Changing Societies. New Haven, CT: Yale University Press.
Ikiara, M., \& Okech, C. (2002). Impact of tourism on environment in Kenya: Status and policy (KIPPRA discussion paper No. 19. Nairobi: Kenya Institute for Public Policy Research and Analysis.

Lau, T. S., \& Hazari, B. R. (2011). Corruption and tourism. Tourism, Trade and Welfare: Theoretical and Empirical Issues. New York: Nova Publishers.

Leff, N. H. (1964). Economic development through bureaucratic corruption. American Behavioral Scientist, 8(3), 8-14.

McGillivray, D., Duignan, M. B., \& Mielke, E. (2019). Mega sport events and spatial management: Zoning space across Rio's 2016 Olympic city. Annals of Leisure Research, 1-24. https://doi.org/10.1080/11745398.2019.1607509

McKercher, B., \& Robbins, B. (1998). Business development issues affecting nature-based tourism operators in Australia. Journal of Sustainable Tourism, 6(2), 173-188.

Méon, P. G., \& Sekkat, K. (2005). Does corruption grease or sand the wheels of growth?. Public Choice, 122(1-2), 69-97. DOI: https://doi.org/10.1007/s11127-005-3988-0

Michael, N., Reisinger, Y., \& Hayes, J. P. (2019). The UAE's tourism competitiveness: A business perspective. Tourism Management Perspectives, 30, 53-64. https://doi.org/10.1016/j.tmp.2019.02.002

Mirzayeva, G., Turkay, O., Akbulaev, N., \& Ahmadov, F. (2020). The impact of mega-events on urban sustainable development. Entrepreneurship and Sustainability Issues, 7(3), 16531666. http://doi.org/10.9770/jesi.2020.7.3(15)

Myrdal, G. (1968). Corruption: its causes and effects. Asian drama: An inquiry into the poverty of nations. The Australian Quaterly, 40(4), 118121.

Neumayer, E. (2004). The impact of political violence on tourism dynamic cross-national estimation. Journal of Conflict Resolution, 48(2), 259-281. DOI: https://doi.org/10.1177/0022002703262358

Nunkoo, R., Ribeiro, M. A., Sunnassee, V., \& Gursoy, D. (2018). Public trust in mega event planning institutions: The role of knowledge, transparency and corruption. Tourism Management, 66, 155-166. https://doi.org/10.1016/j.tourman.2017.11.010

Olmos, L., Bellido, H., \& Román-Aso, J. A. (2020). The effects of megaevents on perceived corruption. European Journal of Political Economy, 61, 101826.

Poprawe, M. (2015). A panel data analysis of the effect of corruption on tourism. Applied Economics, 47(23), 2399-2412. DOI: http://dx.doi.org/10.1080/00036846.2015.1005874

Preuss, H. \& Schu€tte, N. (2016), "Structures of an economic impact: the case of the FIFA football world cup 2014 in Brazil", 7th International Sport Business Symposium, February, 2016.

Ren, K. Y., \& Li, Y. J. (2019). Economic Impact of Mega Sporting Events on Host Country. DEStech Transactions on Social Science, Education and Human Science, 2019. International Conference on Education Reform, Management Innovation and Social Science (ERMISS 2019) pp. 104-110.

Ritchie, J. B., \& Crouch, G. I. (2003). The competitive destination: A sustainable tourism perspective. Cabi.

Roche, M. (2000). Mega-events and modernity: Olympics and expos in the growth of global culture. London: Routledge

Rose-Ackerman, S. (1978). Corruption: a study in political economy. New York: Academic Pres.

Rose-Ackerman, S. (1999). Political corruption and democracy. Connecticut Journal of International Law, 14, 363-631.

Saha, S., \& Yap, G. (2015). Corruption and Tourism: An Empirical Investigation in a Non-linear Framework. International Journal of Tourism Research, 17(3), 272-281. DOI: http://dx.doi.org/10.1002/jtr.1985

Salinas Fernández, J. A., Azevedo, P. S., Martín, J. M. M., \& Martín, J. A. R. (2020). Determinants of tourism destination competitiveness in the countries most visited by international tourists: Proposal of a synthetic index. Tourism Management Perspectives, 33, 100582. 
Serra, D. (2006). Empirical determinants of corruption: A sensitivity analysis. Public Choice, 126 (1-2), 225-256.

Tanzi, V. (1998). Corruption around the world: Causes, consequences, scope, and cures. Staff Papers, 45(4), 559-594.

Tasci, A.D.A., Hahm, J. \& Breiter, D. (2019), "A longitudinal study of Olympic Games' impact on the image of a host country", Journal of Travel \& Tourism Marketing, 36(4), 443-457.

Transperancy International. (2012). Corruption perceptions index 2012. Transparency International: Berlin. Available at: https://www.transparency.org/cpi2012/

Transperancy International. (2015). Corruption perceptions index 2015. Transparency International: Berlin. Available at: https://www.transparency.org/cpi2015/

TTCl - World Economic Forum (2015). The Travel \& Tourism Competitiveness Report 2015. Available at: http://www3.weforum.org/docs/TT15/WEF_Global_Travel\&Tourism_ Report_2015.pdf

Wan, S. K., \& Song, H. (2019). Economic Impact Assessment of MegaEvents in the United Kingdom and Brazil. Journal of Hospitality \& Tourism Research, 43(7), 1044-1067. DOI: 10.1177/1096348019851838

Yap, G., \& Saha, S. (2013). Do political instability, terrorism, and corruption have deterring effects on tourism development even in the presence of UNESCO heritage? A cross-country panel estimate. Tourism Analysis, 18(5), 587-599.

DOI:

http://dx.doi.org/10.3727/108354213X13782245307911

Received: 20.10 .2019

Revisions required: 15.02 .2020

Accepted: 12.03 .2020 